\title{
Gonadotropin-releasing hormone neuropeptides and receptor in human breast cancer: Correlation to poor prognosis parameters
}

\author{
Kalliopi Pazaitou-Panayiotou ${ }^{\mathrm{a}}$, Christina Chemonidou ${ }^{\mathrm{b}}$, Aliki Poupi ${ }^{\mathrm{b}}$, Maria Koureta ${ }^{\mathrm{b}}$, \\ Athina Kaprara ${ }^{b}$, Maria Lambropoulou ${ }^{c}$, Theodoros C. Constantinidis ${ }^{\mathrm{d}}$, Grammati Galaktidou ${ }^{\mathrm{a}}$, \\ Maria Koffa ${ }^{e}$, Anastasia Kiziridou ${ }^{a}$, Stylianos Kakolyris ${ }^{f}$, George Kolios $^{b}$, Alexandros Kortsaris ${ }^{g}$, \\ Ekaterini Chatzaki ${ }^{\mathrm{b}, *}$ \\ a Department of Endocrinology - Endocrine Oncology, "Theagenio" Cancer Hospital, Thessaloniki, Greece \\ ${ }^{\mathrm{b}}$ Laboratory of Pharmacology, Faculty of Medicine, Democritus University of Thrace, Alexandroupolis, Greece \\ ${ }^{\mathrm{c}}$ Laboratory of Histology-Embryology, Faculty of Medicine, Democritus University of Thrace, Alexandroupolis, Greece \\ ${ }^{\mathrm{d}}$ Laboratory of Hygiene and Environmental Protection, Faculty of Medicine, Democritus University of Thrace, Alexandroupolis, Greece \\ e Laboratory of Cellular and Molecular Biology, Department of Molecular Biology and Genetics, Faculty of Medicine, Democritus University of Thrace, Alexandroupolis, Greece \\ ${ }^{\mathrm{f}}$ Department of Oncology, Faculty of Medicine, Democritus University of Thrace, Alexandroupolis, Greece \\ ${ }^{g}$ Laboratory of Biochemistry, Faculty of Medicine, Democritus University of Thrace, Alexandroupolis, Greece
}

\section{A R T I C L E I N F O}

\section{Article history:}

Received 4 September 2012

Received in revised form

14 December 2012

Accepted 17 December 2012

Available online 31 December 2012

\section{Keywords:}

Gonadotropin releasing hormone

Receptor

Neuropeptide

Human

Breast

Cancer

\begin{abstract}
A B S T R A C T
Expression of the two gonadotropin-releasing hormone homologue peptides GnRHI and GnRHII and their receptor GnRHR has been demonstrated in a number of malignancies. In hormone-dependent breast cancer, GnRH analogs are used for therapy in premenopausal women. Gene expression of GnRHI, II and R was studied in breast biopsies from primary breast adenocarcinoma obtained from the tumor and the adjacent benign tissue. Levels were evaluated by a multiplex real-time RT-PCR. GnRHI transcripts were detected in $14.7 \%$ of the benign and $29.4 \%$ malignant biopsies and GnRHII in $21.2 \%$ benign and $44.1 \%$ malignant biopsies. GnRHR was also more frequent in the malignant (54.2\%) than in the benign (24.0\%) biopsies, at similar expression levels. No transcripts were detected in biopsies from healthy individuals. There was a strong correlation between the presence of GnRHI and GnRHII transcripts and their receptor in the benign and the malignant biopsies. GnRHI, II and R expression correlated significantly with poor prognosis pathological parameters. Immunohistochemistry for GnRHR revealed expression in malignant cells and in epithelial cells of mammary ducts of the adjacent area with pre-cancerous features. In contrast, GnRH I and II peptides were rarely expressed at low levels in breast cancer cells. In conclusion GnRH peptides and receptor are expressed more frequently in breast tumors than in the adjacent mammary tissue, representing a malignant feature. Their expression correlated to tumor characteristics of poor prognosis and was therefore related to more aggressive malignancies. Concomitant expression of peptides and receptor supports an autocrine/paracrine regulating role.
\end{abstract}

(c) 2012 Elsevier Inc. All rights reserved.

\section{Introduction}

Gonadotropin-releasing hormone ( $\mathrm{GnRH})$ is a decapeptide produced in the hypothalamus [10]. It interacts with a G-protein coupled receptor (GnRHR) in the anterior pituitary [23], controlling the gonadal function in both sexes. Two human isoforms have been identified, namely GnRH-I and GnRH-II. The first is the hypothalamic isoform responsible for the secretion of $\mathrm{LH}$ and FSH. The second differs by three amino acids [6,27] and is widely distributed in

\footnotetext{
* Corresponding author at: Laboratory of Pharmacology, DUTH, Dragana, Alexandroupolis 68100, Thrace, Greece. Tel.: +30 2551030533; fax: +30 2551030533.

E-mail address: achatzak@med.duth.gr (E. Chatzaki).
}

the central and peripheral nervous system. It is also expressed at significantly higher than GnRH I levels outside the brain and it has been shown to act as a neuromodulator in the behavioral components of reproduction $[16,27,28]$.

GnRH peptides and GnRH $R$ have been found in extrapituitary tissues and tumors of the reproductive and other systems $[4,20,29,34,2]$. Extrapituitary GnRH binding sites are often associated with many novel cellular responses [7]. Furthermore, expression of GnRH R seems to be related with advanced cancer stage in ovarian carcinomas [8].

The GnRH system has been reported to play an autocrine/paracrine role in the inhibition of cellular growth and metastatic potential in breast cancer cell lines [24,35], and breast tumor regression in nude mouse $[14,26]$. However, its expression 
was associated with a protective effect on the chemotherapeutic drug-produced apoptosis [30]. As GnRH agonists (or antagonists) show clinical benefit when used as adjuvant pharmacotherapy in premenopausal breast cancer patients [13], the study of the GnRH system of neuropeptides and receptor in breast tumors remains emerging.

In the present study, the expression of the two GnRH neuropeptide genes (GnRH I, II) and their receptor was evaluated in a series of biopsies from primary breast cancers in a quantitative manner by multiplex real-time RT-PCR. Transcript levels from the malignant tissues were compared to these from the adjacent non-neoplastic tissue and tissues without malignancy, and were correlated to multiple clinicopathological and demographic parameters and clinical output in order to reveal potential prognostic or diagnostic value. Finally, histological mapping of peptide and receptor expression in breast cancer biopsies was done by immunohistochemistry, to reveal specific target cellular types.

\section{Materials and methods}

\subsection{Tissues}

Patients newly diagnosed with primary breast adenocarcinoma in the "Theagenio" Cancer Hospital, Thessaloniki, Greece were enrolled in the study. Biopsies were obtained from the tumor and the adjacent non-neoplastic tissue. Diagnosis was confirmed by the histological examination in all patients. Full medical history, follow-up and histopathological data were available. Patients have not been receiving any hormonal treatment chemotherapy or radiation. Patients with previous or present neoplastic disease at any other site were excluded from the study. Biopsies without signs of malignancy or other pathology obtained for diagnostic use were also used. Human term placenta was obtained by the Obstetrics and Gynecology Department of the General University Hospital in Alexandroupolis. The project was approved by the local Ethical Committee. Consent has been obtained from each patient after full explanation of the purpose and nature of all the procedures used, in accordance to the Helsinki Declaration. Tissue samples were stored in RNAlater (Invitrogen, Carlsbad, CA) at $-80^{\circ} \mathrm{C}$ until used for RT-PCR. Breast cancer tissue sections were also taken from paraffinembedded archival files and used for immunohistochemistry.

\subsection{Cell culture}

The human breast cancer cell lines MDA MB231, MCF7 and T47 were cultured in Dulbecco's Modified Eagle Medium (DMEM) supplemented with $10 \%$ fetal calf serum (FCS) and $1 \%$ penicillin/streptomycin (all purchased from Invitrogen, UK), at $37^{\circ} \mathrm{C}$ in a $5 \% \mathrm{CO}_{2}$ humidified atmosphere. Cells were plated at a concentration of $2 \times 10^{5}$ cells $/ \mathrm{ml}$ and were harvested for total RNA extraction when they had reached approximately $80 \%$ confluence.

\subsection{Multiplex real-time quantitative RT-PCR}

Total RNA was extracted from biopsies using Trizol Reagent, according to the manufacturer's instructions. Reverse transcription (RT) was performed using the SuperScript Preamplification System (Invitrogen) and random hexamers in a total volume of $20 \mu \mathrm{l}$. Two microliter of the same RT product was used as a template for each gene, amplified by PCR using $2 \mathrm{mM} \mathrm{MgCl}_{2}$, PCR buffer, $0.2 \mathrm{mM}$ of sense and antisense primers, $0.2 \mathrm{mM}$ dNTPs and $2.5 \mathrm{U}$ Taq Polymerase (Invitrogen) in a final reaction volume of $50 \mu \mathrm{l}$. Quantitative PCR was performed using the Light Cycler MX3005P (Stratagene, La Jolla, CA) with the following cycling parameters: a pre-amplification cycle (denaturation for $10 \mathrm{~min}$ at $95^{\circ} \mathrm{C}$ ), 40 cycles of amplification (denaturation for $30 \mathrm{~s}$ at $95^{\circ} \mathrm{C}$, annealing for $40 \mathrm{sec}$ at $53^{\circ} \mathrm{C}, 54^{\circ} \mathrm{C}, 50^{\circ} \mathrm{C}$ for GnRH I, GnRH II and GnRH R respectively, and extension for $50 \mathrm{~s}$ at $72^{\circ} \mathrm{C}$ ), and a final dissociation cycle $\left(1 \mathrm{~min}\right.$ at $95^{\circ} \mathrm{C}, 40 \mathrm{~s}$ at $57^{\circ} \mathrm{C}$ and $30 \mathrm{sec}$ at $\left.95^{\circ} \mathrm{C}\right)$. Primers were designed according to the GenBank published sequences as follows: for human GnRH R sense 5'-CCTTGTCTGGAAAGATCCGA$3^{\prime}$ and antisense 5'-GGAGCGGTCCAGGCTGAT-3' [33], for human GnRH I sense 5'-CTACTGACTTGGTGCGTGGA-3' and antisense 5'CTGCCCAGTTTCCTCTTCAA- $3^{\prime}$ and for human GnRH II sense $5^{\prime}$-TCCTGCTGCTGCTGACTG-3' and antisense 5'- CTAAGGGCATTCTGGGGAT-3' [25]. Product sizes were 319, 240 and 119bp for GnRH $\mathrm{R}, \mathrm{GnRH}$ I and GnRH II respectively. Reactions in duplicate were carried out using the SYBER Green MM QPCR Brilliant mix (Stratagene), $0.4 \mu \mathrm{M}$ of each primer, $2 \mathrm{mM} \mathrm{MgCl}_{2}$ and $0.5 \mu \mathrm{L}$ of cDNA in a final volume of $20 \mu \mathrm{L}$. Results were calculated using MaxPro QPCR Software Version 4.0 (Stratagene) using the comparative threshold cycle method. Analysis of relative gene expression data was performed according to the $2^{-\Delta \Delta C_{T}}$ method [21] using $\beta$-actin as a reference gene and RNA from human placenta as a positive control. Results are expressed as the mean from duplicate values of gene expression in relation to $\beta$-actin in the same RNA preparation. Samples with poor $\beta$-actin gene amplification were excluded from the study. Negative control samples, where no RT enzyme was added (no RT) or without DNA template (no DNA), were included in every assay in order to exclude the possibility of genomic or other DNA contamination.

\subsection{Immunohistochemistry}

Immunohistochemistry was conducted as previously described [32]. Briefly, tissue specimens were fixed in formalin and embedded in paraffin. Sections $(4 \mu \mathrm{m})$ were deparaffinized, rehydrated, and treated with $0.3 \% \mathrm{H}_{2} \mathrm{O}_{2}$ for $5 \mathrm{~min}$ in methanol. Slides were incubated for $75 \mathrm{~min}$ with primary mouse monoclonal antibodies for human GnRH R (ab22168, Abcam, UK), GnRH I (HU11B, SantaCruz Biotechnology Inc., CA, USA) and GnRH II (D-9, SantaCruz Biotechnology Inc.) diluted 1:250, 1:100 and 1:100 respectively in $10 \%$ normal mouse serum in PBS. Negative control slides were incubated for the same period with normal mouse serum IgG. Immunostaining was detected by the Kwik Kit (Thermo Shandon, Pittsbutgh, PA, USA). Finally, bound antibody complexes were stained for $10 \mathrm{~min}$ with $0.05 \%$ diaminobenzidine, counterstained with Mayer's hematoxylin, mounted and examined under an Olympus BX40 microscope.

\subsection{Statistical analysis}

All measurements were done in duplicate. Statistical significance was assessed by Mann-Whitney U-Wilcoxon Rank Sum W Test, using the SPSS 17.0 statistical software (SPSS Inc., Chicago, IL, USA). Group differences were assessed by chi square test. Significance was set at a $p$ value $<0.05$. Analysis of the data in pairs of benign and malignant biopsies from the same patient was performed by the McNemar test. Kaplan Meier survival analysis was also performed.

\section{Results}

\subsection{Patient and tumor information}

Thirty-five women with primary breast cancer were enrolled in the study, with mean age $61 \pm 13$ years, mean BMI $28.9 \pm 5.4 \mathrm{~kg} / \mathrm{m}^{2}$ and mean age of menarche $13 \pm 1.3$ years. At the time of diagnosis, $27 / 35$ (71.4\%) were menopausal with mean age of menopause $48.5 \pm 3.9$ years. Two of them did not report any history of pregnancy, whereas for the rest the mean number of full-term pregnancies was $1.9 \pm 0.8$, with mean age of first pregnancy $25.1 \pm 4.3$ 
Table 1

Patient's histopathological findings.

\begin{tabular}{|c|c|c|}
\hline Characteristic & No. of patients & Percentage \\
\hline \multicolumn{3}{|l|}{ Tumor size } \\
\hline$<2 \mathrm{~cm}^{2}$ & $14 / 35$ & 40.0 \\
\hline$>2 \mathrm{~cm}^{2}$ & $21 / 35$ & 60.0 \\
\hline \multicolumn{3}{|l|}{ Type } \\
\hline Duct and other & $30 / 35$ & 85.7 \\
\hline Lobular & $5 / 35$ & 14.3 \\
\hline \multicolumn{3}{|l|}{ Grade } \\
\hline I & $6 / 35$ & 17.1 \\
\hline II & $18 / 35$ & 51.4 \\
\hline III & $8 / 35$ & 22.9 \\
\hline IV & $3 / 35$ & 8.6 \\
\hline \multicolumn{3}{|l|}{ Infiltration } \\
\hline No & $19 / 35$ & 54.3 \\
\hline Yes & $16 / 35$ & 45.8 \\
\hline \multicolumn{3}{|l|}{ Lymph nodes } \\
\hline 0 & $15 / 35$ & 42.9 \\
\hline 1 & $6 / 35$ & 17.1 \\
\hline$>2$ & $14 / 35$ & 40.0 \\
\hline \multicolumn{3}{|l|}{ Metastasis } \\
\hline no & $32 / 35$ & 91.4 \\
\hline yes & $3 / 35$ & 8.6 \\
\hline \multicolumn{3}{|c|}{ Estrogen receptors } \\
\hline$(+)$ & $25 / 35$ & 71.4 \\
\hline$(-)$ & $10 / 35$ & 28.6 \\
\hline \multicolumn{3}{|c|}{ Progesterone receptors } \\
\hline$(+)$ & $22 / 35$ & 62.8 \\
\hline$(-)$ & $10 / 35$ & 27.2 \\
\hline \multicolumn{3}{|l|}{$c$-erbB2 } \\
\hline$(+)$ & $12 / 35$ & 34.2 \\
\hline$(-)$ & $23 / 35$ & 65.8 \\
\hline
\end{tabular}

years and mean duration of lactation for all children $11.2 \pm 12.8$ months. Mean value for pregnancy terminations was $0.8 \pm 1.0$. One of them (2.85\%) reported alcohol consumption $(\leq 250 \mathrm{ml} /$ day of drink with $5-10 \%$ alcohol) and $4 / 35$ (11.4\%) had been administered contraceptive pills ( $0.25-2$ years). Their education level was at $21 / 35(60.0 \%)$ basic, $10 / 35$ (28.5\%) high-school and $4 / 35(11.4 \%)$ university. 17/35 (48.5\%) had family history of malignancy and 5/35 (14.2\%) in breast. $3 / 35$ (8.5\%) had been previously diagnosed with benign breast disease. None of the patients had received radiation for any reason or had history of other malignancy or syndrome.

The clinicopathological findings of the tumors by pathological examination based on the TNM system of the American Joint Committee on Cancer, used in the study are shown in Table 1.

Follow-up for 24-68 months showed disease relapse in 4/32 (12.5\%) cases. In 3 patients follow-up was not possible. One patient developed endometrial adenocarcinoma 36 months after initial diagnosis, and exacerbation was reported in the patient with liver metastasis. At the completion of the study, 26/32 (81\%) patients were disease-free, $4 / 32$ (13\%) still had disease and 2/32 (6\%) died.

\subsection{Levels of gene expression of GnRH neuropeptides and receptor in breast cancer biopsies}

GnRH I, II and R gene expression was examined by comparative real-time RT-PCR in human breast cancer biopsies and in the adjacent non-malignant tissue. PCR products were denaturating at the same temperature as the product from human term placenta used as positive control.

GnRH I gene transcripts were found twice as frequently in the malignant $(10 / 34,29.4 \%)$ than the benign biopsies $(5 / 34,14.7 \%)$ examined. Transcript levels did not differ between benign and malignant biopsies in a statistically significant manner, being $92 \times 10^{-3} \pm 60 \times 10^{-3}$ and $129 \times 10^{-3} \pm 95 \times 10^{-3}$, respectively. When analysis was performed in pairs of benign and malignant biopsies from the same patient, it was found that in $18 / 26$ (69.2\%) cases both biopsies were negative, in 4/26 (15.4\%) only the malignant biopsy was positive, in $2 / 26$ (7.7\%) only the benign biopsy was positive and in $2 / 26$ ( $7.7 \%$ ) both biopsies were positive (Fig. 1).

GnRH II transcripts were found in $7 / 33$ (21.2\%) of the benign biopsies examined and in 15/34 (44.1\%) of the malignant biopsies and this difference was statistically significant $(p=0.04)$. Transcript levels, as compared to the expression levels found in human term placenta, did not differ between benign and malignant biopsies in a statistically significant manner, being $17 \times 10^{-3} \pm 11 \times 10^{-3}$ and $55 \times 10^{-3} \pm 30 \times 10^{-3}$ respectively. When analysis was performed in pairs of benign and malignant biopsies from the same patient, it was found that in $12 / 24(50.0 \%)$ cases both biopsies were negative, in $7 / 24$ (29.2\%) only the malignant biopsy was positive, in 3/24 (12.5\%) only the benign biopsy was positive and in $2 / 24$ (8.3\%) both biopsies were positive (Fig. 2).

GnRH R gene expression was found to be more frequent in the malignant biopsies $(13 / 24,54.2 \%)$ compared to the benign biopsies (6/25, (24.0\%), in a statistical significant manner $(p=0.05) . \mathrm{GnRH}$ $\mathrm{R}$ transcript levels, expressed in relation to human term placenta, were also higher in the malignant tissues $\left(430 \times 10^{-3} \pm 365 \times 10^{-3}\right)$ in comparison to the benign $\left(91 \times 10^{-3} \pm 54 \times 10^{-3}\right)$ although this difference was not statistically significant. When analysis was performed in pairs of malignant and benign biopsies from the same patient, the following pattern was revealed regarding GnRH R expression; in 8/16 (50.0) patients GnRH R transcripts were absent in both biopsies, in 4/16 (25.0\%) were present in both biopsies, in $4 / 16$ (25.0\%) GnRH R was expressed only in the malignant tissues, whereas in none $(0.0 \%)$ of the patients transcripts were found in the benign but not in the malignant biopsy (Fig. 3).

Interestingly, statistical analysis revealed a correlation between GnRH R gene expression in the tumor biopsy and in the corresponding adjacent area $(p=0.021)$. No such significant correlation was found for the two neuropeptide genes. However, receptor expression in the benign tissue correlated positively with the presence of GnRH I $(p=0.019)$ but not GnRH II transcripts $(p=0.062)$ in the same tissues. In addition, receptor expression in the malignant biopsies correlated positively with the presence of GnRH I $(p=0.008)$ and also GnRH II transcripts $(p=0.001)$. Finally, there was a strong statistically significant correlation $(p<0.0001)$ regarding the presence of GnRH I and GnRH II transcripts in both the benign and the malignant biopsies. Breast biopsies from 5 patients that were diagnosed to have no malignancy where found to express none of the three genes.

Statistical analysis was performed in order to reveal significant correlations of GnRH neuropeptide and receptor expression and expression levels with any of the patient histopathological characteristics, including tumor size, type, grade, infiltration, lymph nodes, metastasis, estrogen or progesterone receptors and c-erbB2. Detection of GnRH I in the cancer biopsies correlated significantly with the size of the tumor $(p=0.04)$, while detection and increased expression levels correlated with infiltration $(p=0.02)$. Expression levels of GnRH I in the adjacent benign biopsies correlated significantly with the absence of PR $(p<0.001)$ and presence $c$ erbB2 $(p=0.05)$ in the tumor, whereas expression levels of GnRH II correlated with absence of ER. In addition, the levels of GnRH $\mathrm{R}$ expression were correlated with infiltration $(p<0.001)$, whereas the presence of GnRH R correlated with higher BMI $(p=0.04)$.

No other statistical correlation was found between the expression of the three genes and the histopathological characteristics of the tumors as well as with age, weight, height, BMI, age of menarche, children birth, age of first pregnancy, duration of lactation, age of menopause, abortions, alcohol use, education level, familial breast history, familial cancer history and benign breast disease of the patients. Finally, no correlation was found between GnRH I and II and GnRH R expression in both benign and malignant tissues with disease relapse and patient survival (Kaplan Meier analysis). 
A

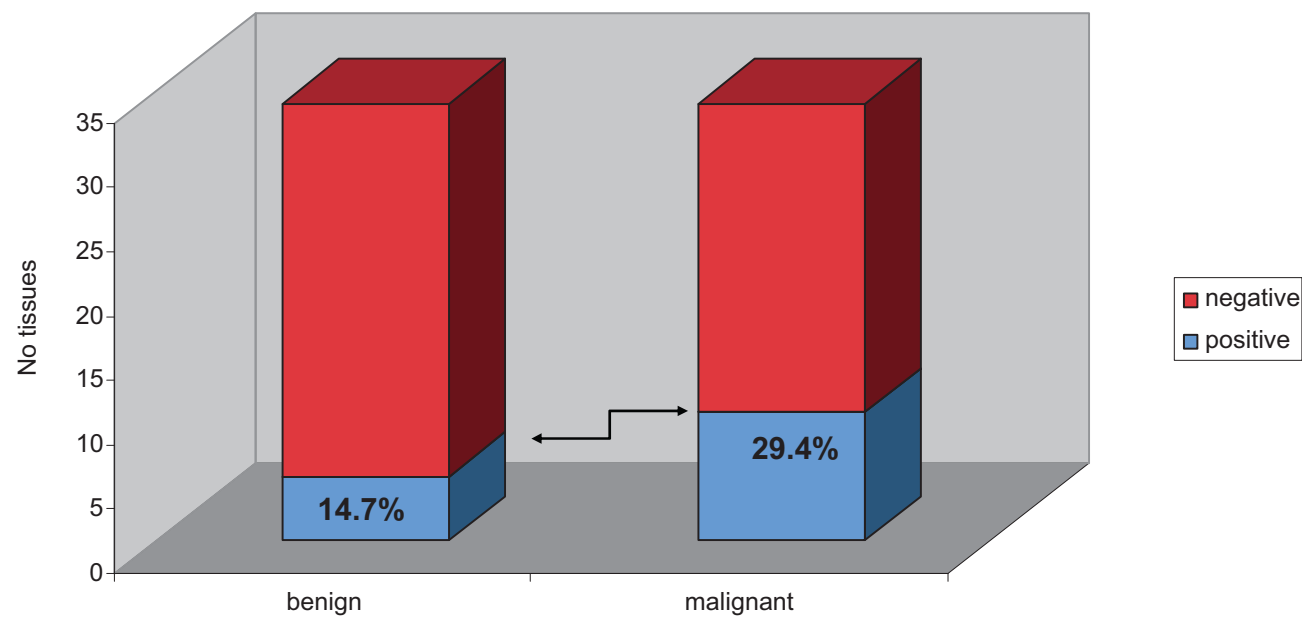

B

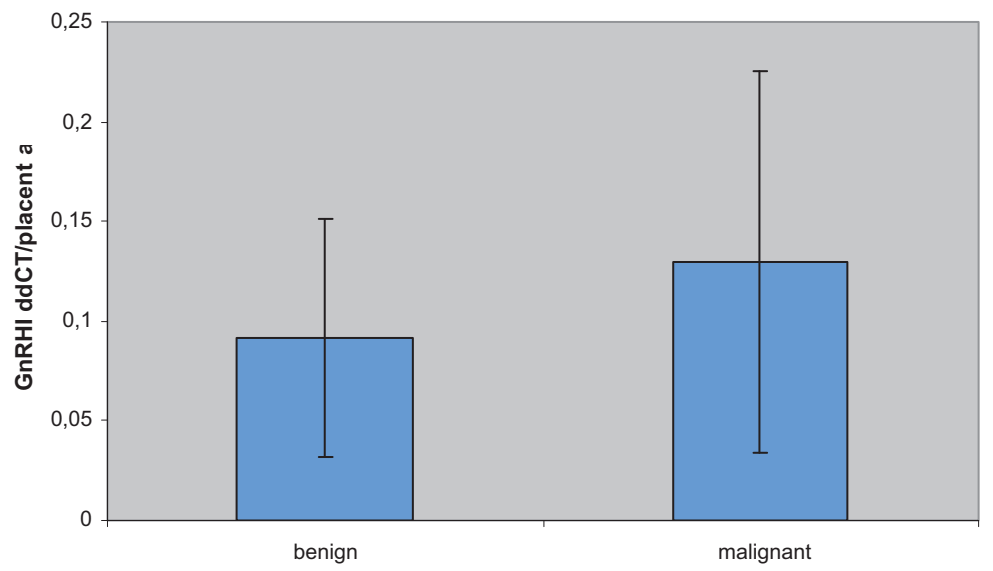

\begin{tabular}{c|c|c|c} 
CnRHI & benign & malignant & No of tumors (\%) \\
\hline & $(-)$ & $(-)$ & $18 / 26(69.2 \%)$ \\
\hline & $(-)$ & $(+)$ & $4 / 26(15.4 \%)$ \\
\hline & $(+)$ & $(-)$ & $2 / 26(7.7 \%)$ \\
\hline & $(+)$ & $(+)$ & $2 / 26(7.7 \%)$
\end{tabular}

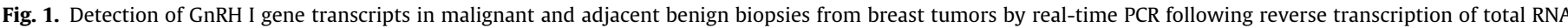

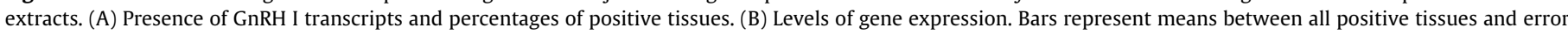
bars the standard deviation between measurements. (C) Expression in malignant biopsies in relation to their adjacent benign tissue.

\subsection{Levels of gene expression of GnRH neuropeptides and receptor in breast cancer cell lines}

Expression of the three genes was also examined in the human breast cancer cell lines MDA MB231, MCF7 and T47. All cell lines expressed low levels of GnRH I $\left(0.50 \times 10^{-3}, 0.06 \times 10^{-3}\right.$ and $34.70 \times 10^{-3}$ units in relation to human placenta, respectively) and GnRH II $\left(0.60 \times 10^{-3}, 0.05 \times 10^{-3}\right.$ and $16.70 \times 10^{-3}$ units in relation to human placenta, respectively), whereas $\mathrm{GnRH} R$ was found in MDA MB231 and MCF7 $\left(3.4 \times 10^{-3}\right.$ and $0.2 \times 10^{-3}$ units in relation to human placenta, respectively), but not in T47.

\subsection{Expression of GnRH peptides and GnRH R protein in breast cancer biopsies}

Immunohistochemical analysis was used in order to detect GnRH peptides and GnRH R protein expression in 16 human breast tumor biopsies and to localize it at histological and cellular level. Immunoreactivity for GnRH I was found in breast cancer cells in 5 out of 16 tissues (31.25\%), localized in perineural invasions, implants and macrophages (Fig. 4). Similarly, the majority of the tumors were negative for GnRH II. Immunoreactivity was found in 5 out of 16 tissues, being also positive for $\mathrm{GnRH}$ I, in breast cancer 
A
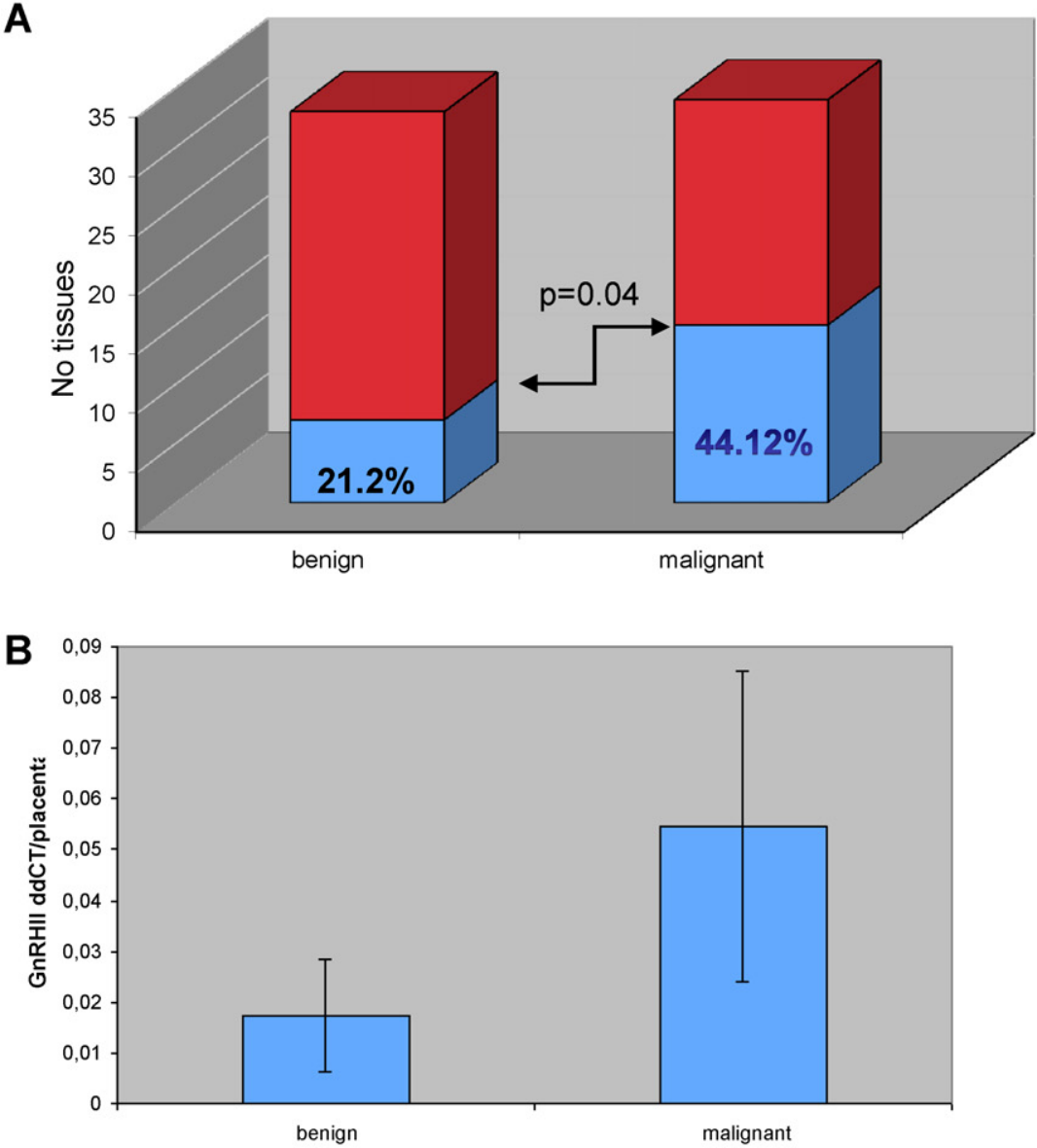

\begin{tabular}{c|c|c|c} 
GnRHII & benign & malignant & No of tumors (\%) \\
\hline & $(-)$ & $(-)$ & $\mathbf{1 2 / 2 4 ( 5 0 \% )}$ \\
\hline & $(-)$ & $(+)$ & $\mathbf{7 / 2 4 ( 2 9 . 2 \% )}$ \\
\hline & $(+)$ & $(-)$ & $\mathbf{3 / 2 4}(\mathbf{1 2 . 5 \% )}$ \\
\hline & $(+)$ & $(+)$ & $\mathbf{2 / 2 4 ( 8 . 3 \% )}$
\end{tabular}

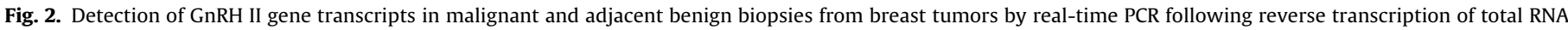

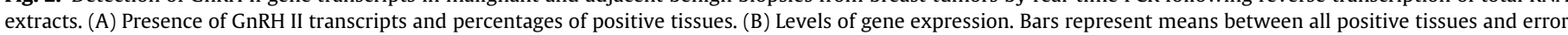
bars the standard deviation between measurements. (C) Expression in malignant biopsies in relation to their adjacent benign tissue.

cells and in cancer implants, and in infiltrating macrophages (Fig. 5). Epithelial cells of cancerous implants of a mucinous carcinoma studied were positive for both GnRH I (Fig. 4C) and II (Fig. 5C). Immunoreactivity in all cases was cytoplasmic and mild, not uniform in all areas of the tissue section but rather occasional. The adjacent to the tumor area showed no immunoreactivity for both antibodies. Human term placenta, used as a positive control, showed strong cytoplasmic immunoreactivity (Figs. 4E and 5E). No specific staining was found in any cell type after replacement of the primary antibody by non-specific mouse IgG (negative control in placenta and breast cancer, Figs. $4 \mathrm{~F}$ and $5 \mathrm{~F}$ respectively).

Tissue sections were also stained using monoclonal antibodies against the N-terminus of human GnRH R. Representative areas of the sections are presented in Fig. 6. Positive GnRH R staining was localized in malignant cells of the tumor which varied in size and shape $(A-C)$ and in the cancerous implants of ductal in situ carcinoma of solid type with (B) or without (A) inflammation (aggregates of periductal mononuclear inflammatory cells), and in macrophages scattered in a negative stroma. Immunostaining was clearly membranic but also cytoplasmic (C). In the adjacent to the tumor area, epithelial cells of mammary ducts presenting features of atypia, lack of polarity, enlarged nuclei, prominent nucleoli and numerous mitosis, showed some immunoreactivity for the GnRH receptor, mainly cytoplasmic (B). Finally, cancer cells of perineural invasions were negative (D). 
A

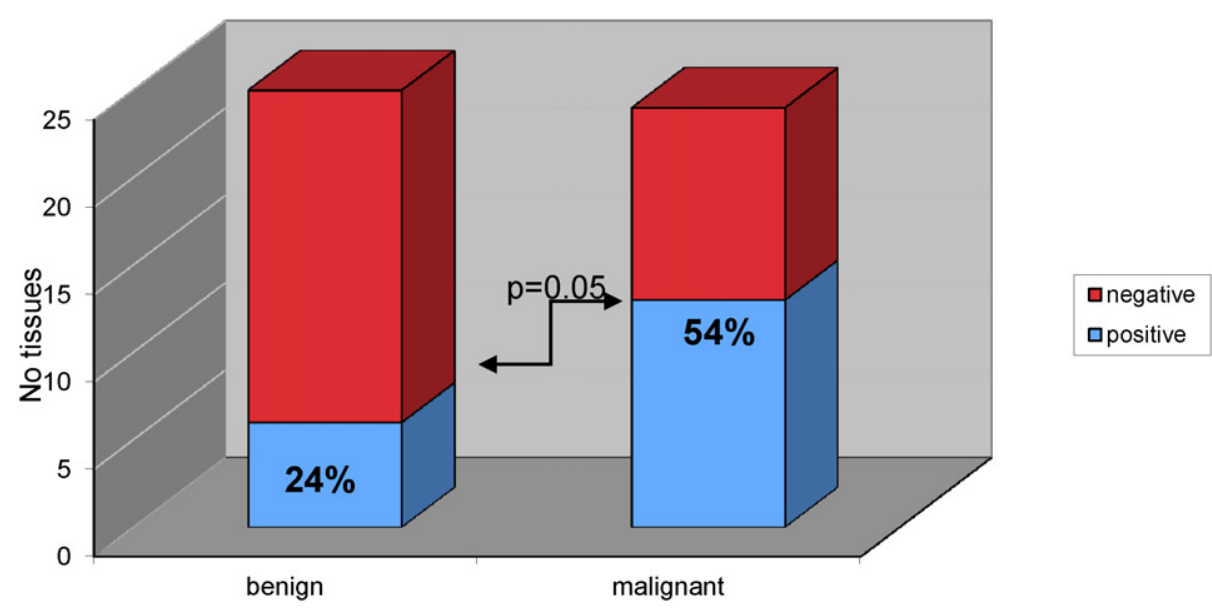

B

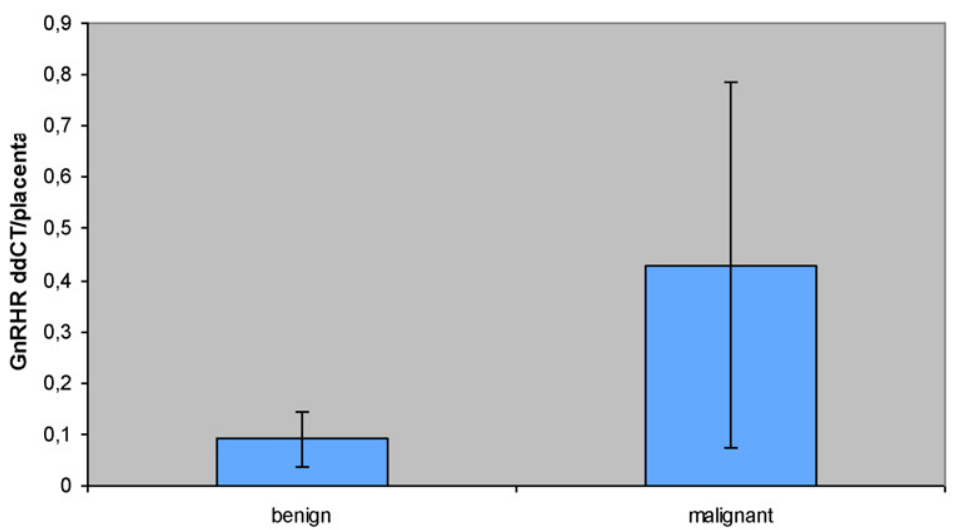

\begin{tabular}{c|c|c|c} 
GnRHR & benign & malignant & No of tumors (\%) \\
\hline & $(-)$ & $(-)$ & $\mathbf{8} / 16(50.0 \%)$ \\
\hline & $(-)$ & $(+)$ & $4 / 16(25.0 \%)$ \\
\hline & $(+)$ & $(-)$ & $\mathbf{0 / 1 6 ( 0 . 0 \% )}$ \\
\hline & $(+)$ & $(+)$ & $\mathbf{4 / 1 6 ( 2 5 . 0 \% )}$
\end{tabular}

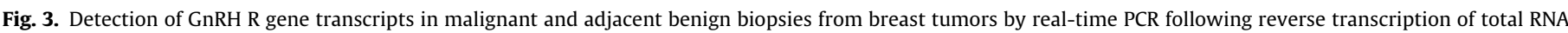

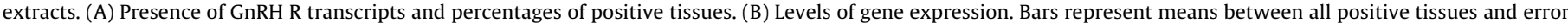
bars the standard deviation between measurements. $(C)$ Expression in malignant biopsies in relation to their adjacent benign tissue.

\section{Discussion}

The two GnRH neuropeptides (GnRH I and II) and their receptor are key players of the nervous system control on the reproductive function. Their expression however has also been clearly established in many extra-pituitary organs in reproductive and non-reproductive tissues and tumors arising there, breast cancer being one of the first reported [7]. Ectopic expression of neuropeptides is frequently found in endocrine cancers. Their role seems to contribute to the cancer biology via activation of locally expressed receptors in an autocrine manner or a paracrine dia$\log$ in the tumor microenvironment between the tumor cells and the nearby located cells, such as stroma, immune cells or by innervating autonomic neurons. Breast cancer tumors are known to express multiple neuropeptides and their receptors such as CRF, GHRH and somatostatin along with GnRH, firstly studied in breast cancer by immunohistochemistry [9]. We have recently reported the expression of both CRF receptors in breast cancer and the respective benign adjacent tissue, which could serve as targets of endogenous ligands regulating cancer growth [15]. In the present study we quantify gene expression of GnRH I and II along with GnRH R in human breast tumors. It is important that two biopsies were collected by the same patient, one from the breast cancer tissue and one from the adjacent benign tissue and results in the actual tumor were compared with those from its pre-cancerous milieu. 

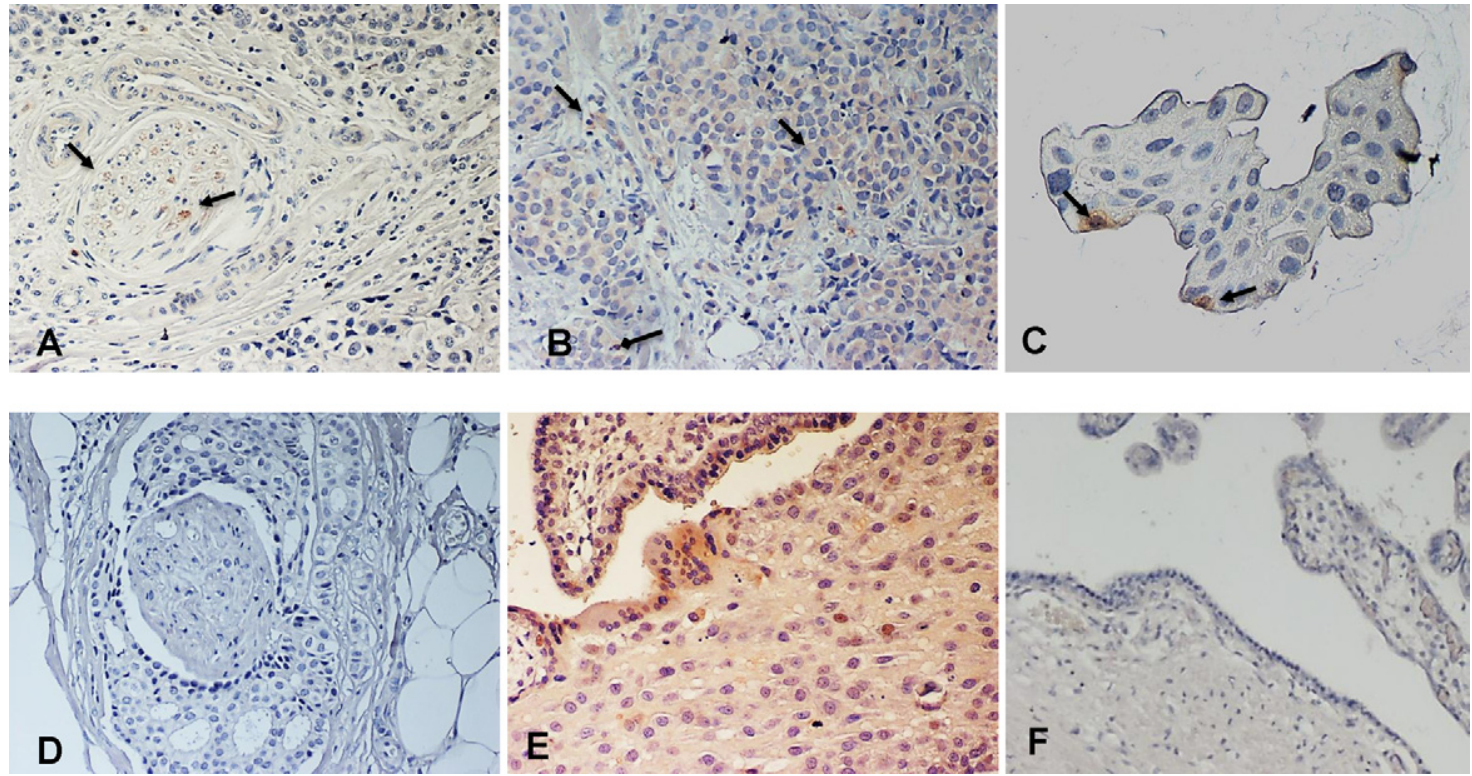

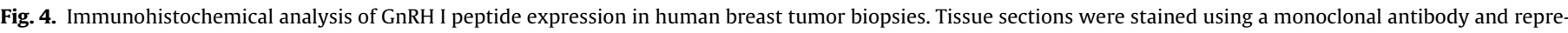

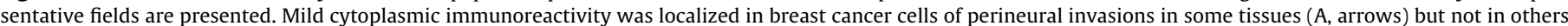

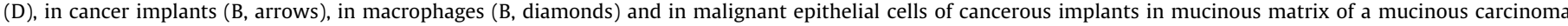

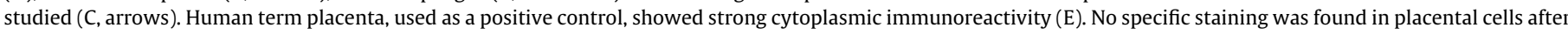
replacement of the primary antibody by non-specific mouse IgG (F). Original magnification $200 \times(A, B, D, F, E), 400 \times(C)$.

GnRH I and GnRH II gene transcripts were found approximately twice as frequent in the malignant than in the benign biopsies, implying that they present a characteristic accompanying malignant transformation. Transcript levels showed no statistically significant differences between malignant and benign biopsies for either gene. This is in accordance with previous findings of semi-quantitative determinations of GnRH I mRNA in a small number of tissues [19]. Chen et al., 2002 [5] however, reported higher levels of GnRH I and GnRH II in the malignant biopsies of breast in comparison with the adjacent benign tissue, as detected in 6 breast cancer patients by semi-quantitative RT-PCR, attributed to the overall high protein expression and enhanced transcription machinery that exist in cancer cells. The great variability found in the expression levels between the positive samples might have prohibited statistically significant differences to emerge in our study, which however employs a strictly quantifying method correcting for the total protein content (using actin as a house-keeping gene) and a much larger number of tissues.
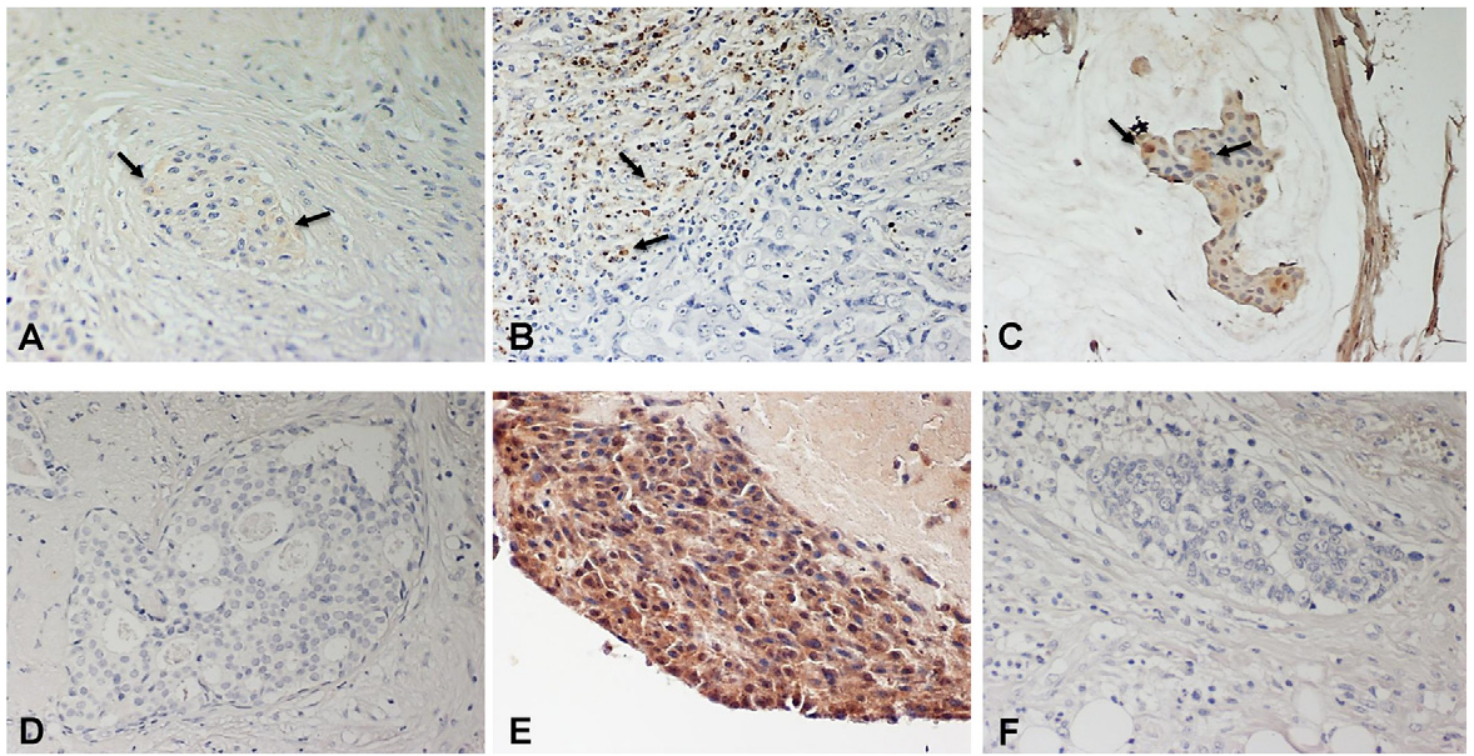

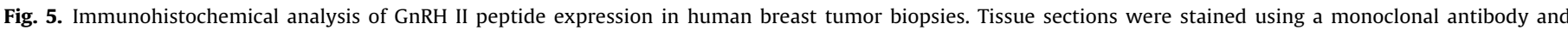

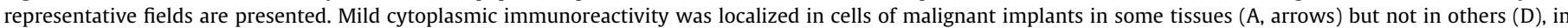

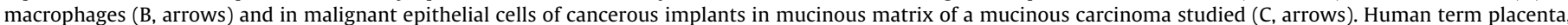

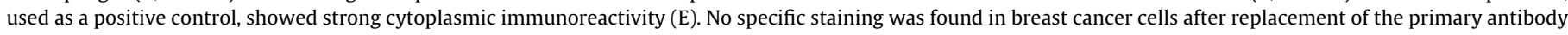
by non-specific mouse $\operatorname{IgG}(\mathrm{F})$. Original magnification $200 \times$. 

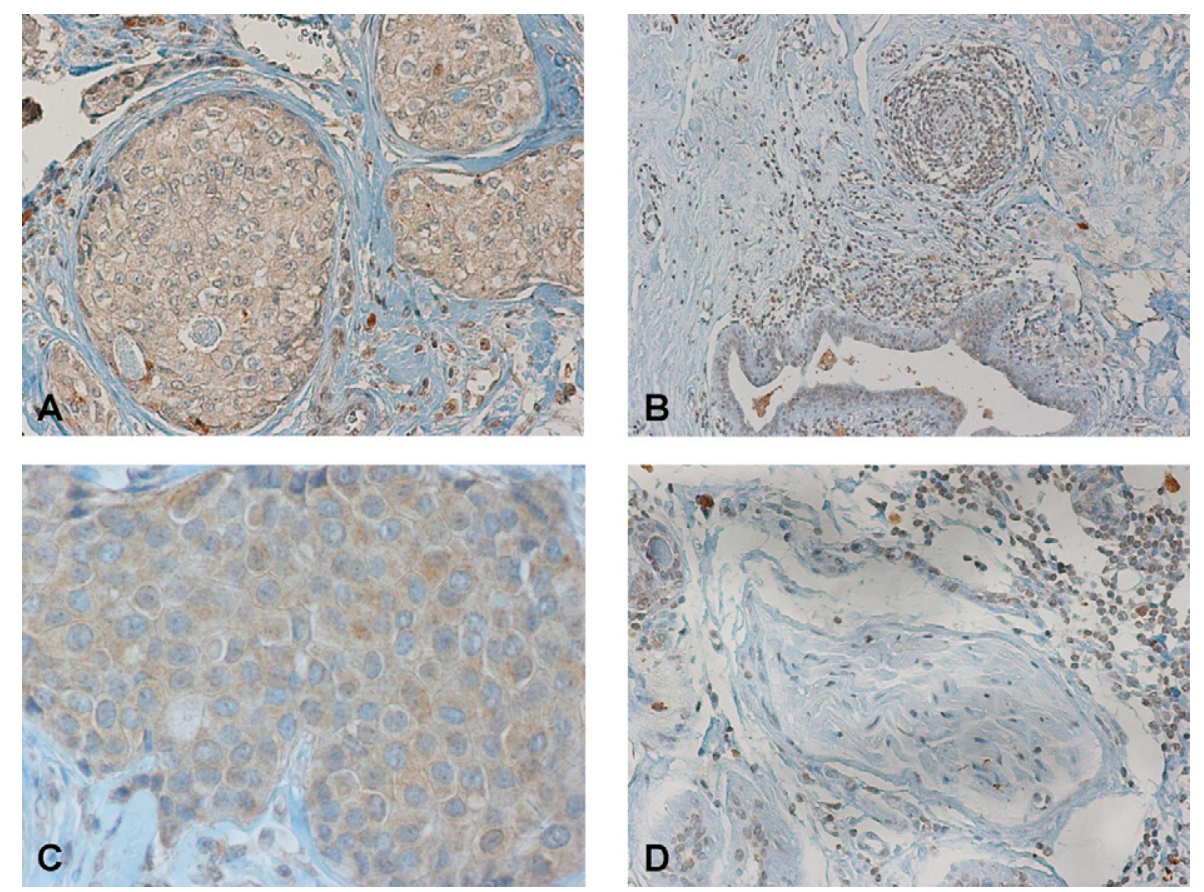

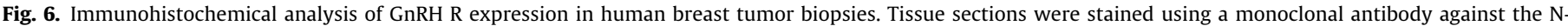

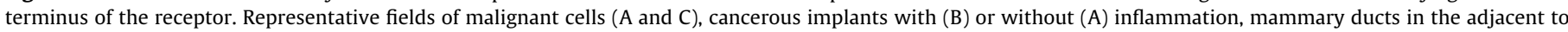

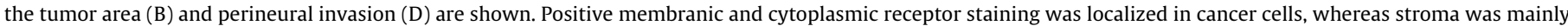
negative. Original magnification $100 \times(B), 200 \times(A$ and $D), 400 \times(C)$.

At the peptide level, GnRH I and II were expressed rarely by breast cancer cells, as shown by immunohistochemical analysis using monoclonal antibodies. Low cytoplasmic immunoreactivity was found in $31.25 \%$ of the samples, a percentage similar to the mRNA positive tissues. Antigen was localized in some breast cancer cells of perineural invasions, implants and macrophages (Fig. 4). These results are in agreement to the study of Chen et al., 2002, showing GnRH I and II peptide immunoreactivity in 8 out of 14 breast cancer biopsies using polyclonal anti-serums. The adjacent to the tumor area showed no immunoreactivity for both antibodies. It is possible that post-transcriptional regulation mechanisms prevent peptide expression at the benign tissue. In fact, this was also the case in endometrial tissues and cell lines [4], in which GnRH transcripts were abundant but no secreted peptide was found by RIA. These mechanisms must be altered in certain malignant transformed cells, where peptides can be traced.

GnRH R transcripts were also found at higher frequency the malignant (54.2\%) than the benign biopsies examined (24.0\%), and at higher levels. Interestingly, in all cases found positive in the benign tissue, this was accompanied by transcript presence in the corresponding malignant biopsy, indicating that it could represent a pre-malignant feature of the mammary tissue. Indeed, GnRH R in the tumor biopsy correlated significantly to its presence in the corresponding adjacent area. GnRH R expression was also studied at the protein level by immunohistochemistry. Receptor was localized in the membranes but also in the cytoplasm of malignant cells of the tumor and in the cancerous implants of ductal in situ carcinoma of solid type, in accordance with previous reports [1,22]. Perineural invasions were negative. Adjacent to the tumor area, epithelial cells of mammary ducts presenting pre-cancerous characteristics were also positive, further supporting an early tumorigenesis event. Differential expression of GnRH R by different cell types within the tumor could explain the great variability in gene expression levels estimated by real-time RT-PCR. Mammary samples from patients without any malignancy were negative for both $\mathrm{GnRH}$ peptide and receptor gene expression.
GnRH I expression correlated significantly with the size and infiltration of the tumor in the cancer biopsies, while in the adjacent benign biopsies it correlated with absence of progesterone receptors and c-erbB2 positivity of the tumor. GnRH II was expressed more frequently than GnRH I in the same tissues, and its expression levels correlated with absence of ER. In addition, levels of GnRH R correlated with infiltration and higher patient BMI. All these parameters are negative biomarkers of breast cancer and therefore correlate GnRH system expression to more aggressive and poorer prognosis disease. Our results imply that GnRH system expression could hold a clinical prognostic potential for breast cancer. Fortunately, only 3 patients from our sample deceased and 6 developed metastasis in a 5-year follow up, making survival analysis in relation to GnRH gene expression inconclusive.

Specific binding sites for GnRH were demonstrated in human breast carcinomas but not in non-neoplastic breast tissue by ligand immunoblotting back in 1985 [18]. The percentage of GnRH R positive tissues here (54.2\%) is in line with previous reports detecting binding sites by a multipoint assay [11]. Our study confirms that they represent the protein product of this gene. Similarly, the low affinity GnRH-binding sites described in human breast cancer cell lines (ZR-75-1, MDA-MB-231, Sk Br 3, MDA-MB-157 and MCF-7) [18] obviously represent the GnRH R gene product detected here in MDA-MB231 and MCF7 but not in T47 human breast cancer cell lines. The high GnRH neuropeptide levels detected in T47 might down-regulate receptor expression. The levels of gene expression in all the cell lines were lower that these detected in the breast cancer biopsies, but no direct comparisons can be done, due to the great variability between tissues and the heterogeneity and complexity of the cellular types in tissues (i.e. epithelial, stromal, macrophages etc. in the biopsies) vs. an epithelial cancer cell clone in the cell lines. This however might not be reflected at the translational level, as GnRH peptide expression has been shown before in MCF7 cells and extensively characterized with multiple approaches (HPLC, confocal microscopy) [5]. 
Co-expression of GnRH peptide and receptor in human breast tissues support an autocrine/paracrine role in human mammary gland. This is further supported by our analysis showing that receptor expression in the benign and malignant tissues correlated positively with the presence of $\mathrm{GnRH}$ neuropeptide transcripts. In addition, there was a strong correlation between the presence of GnRH I and GnRH II transcripts in both the benign and the malignant biopsies, indicating the concomitant expression of both neuropeptide isoforms in breast, confirmed also by immunohistochemistry. Overall, it seems that the full neuropeptide and receptor system is simultaneously expressed in some tissues and this could be the result of inter-activation between the genes of the system, although this does not seem to be the case at least for the peptides [3]. Alternatively, co-activation of the three genes could be a concurrent response to the same stimulant. Several studies have shown differential regulation of the GnRH-I and GnRH-II genes by gonadotrophs and steroid hormones in extrapituitary sites. However, other effectors and factors should be examined for their ability to transcriptionally activate GnRH genes [17] and breast cancer cell lines reported here to express both peptides and receptor could serve as a convenient in vitro model for such studies.

\section{Conclusions}

Growth effects of GnRH analogs on breast cancer cells depend on the amount of GnRH at cell surfaces and on receptor functionality [12,31], therefore quantification of expression levels holds a specific interest to predict cellular responses. Furthermore, GnRH receptors may contribute to the breast tumor responsiveness to pharmacotherapy with GnRH analogs and thus estimation of expression levels could define a more sensitive patient subpopulation. Our results add to the pathophysiological significance of the GnRH system in breast cancer biology possibly by contributing to the dialog between benign and malignant cell types, and imply that its quantification could complement the clinicopathological profiling of breast cancer with potential clinical exploitation in prognosis and treatment.

\section{Conflict of interest}

\section{All authors declare that they have no conflict of interest.}

\section{Contributors}

Kalliopi Pazaitou-Panayiotou, Alexandros Kortsaris and Ekaterini Chatzaki designed the study, Christina Chemonidou, Aliki Poupi, Maria Koureta and Maria Koffa performed the experiments, Maria Lambropoulou, Theodoros C. Constantinidis and Grammati Galaktidou analyzed the results, Athina Kaprara, Anastasia Kiziridou and Stylianos Kakolyris collected biologic material and clinical information, Kalliopi Pazaitou-Panayiotou, George Kolios and Ekaterini Chatzaki prepared the manuscript.

All authors have approved the final article.

\section{References}

[1] Abd-Elaziz M, Akahira J, Moriya T, Suzuki T, Yaegashi N, Sasano H. Nuclear receptor DAX-1 in human common epithelial ovarian carcinoma: an independent prognostic factor of clinical outcome. Cancer Sci 2003;94: 980-5.

[2] Aguilar-Rojas A, Huerta-Reyes M. Human gonadotropin-releasing hormone receptor-activated cellular functions and signaling pathways in extra-pituitary tissues and cancer cells. Oncol Rep 2009;22:981-90 (Review).

[3] Baldwin EL, Wegorzewska IN, Flora M, Wu TJ. Regulation of type II luteinizing hormone-releasing hormone (LHRH-II) gene expression by the processed peptide of LHRH-I, LHRH-(1-5) in endometrial cells. Exp Biol Med (Maywood) 2007;232:146-55

[4] Chatzaki E, Bax CM, Eidne KA, Anderson L, Grudzinskas JG, Gallagher CJ. The expression of gonadotropin-releasing hormone and its receptor in endometrial cancer, and its relevance as an autocrine growth factor. Cancer Res 1996;56:2059-65.

[5] Chen A, Kaganovsky E, Rahimipour S, Ben-Aroya N, Okon E, Koch Y. Two forms of gonadotropin-releasing hormone $(\mathrm{GnRH})$ are expressed in human breast tissue and overexpressed in breast cancer: a putative mechanism for the antiproliferative effect of $\mathrm{GnRH}$ by down-regulation of acidic ribosomal phosphoproteins P1 and P2. Cancer Res 2002;62:1036-44.

[6] Chen A, Yahalom D, Ben-Aroya N, Kaganovsky E, Okon E, Koch Y. A second isoform of gonadotropin-releasing hormone is present in the brain of human and rodents. FEBS Lett 1998;435:199-203.

[7] Cheung LW, Wong AS. Gonadotropin-releasing hormone: GnRH receptor signaling in extrapituitary tissues. FEBS J 2008;275:5479-95.

[8] Chien CH, Chen CH, Lee CY, Chang TC, Chen RJ, Chow SN. Detection of gonadotropin-releasing hormone receptor and its mRNA in primary human epithelial ovarian cancers. Int J Gynecol Cancer 2004;14:451-8.

[9] Ciocca DR, Puy LA, Fasoli LC, Tello O, Aznar JC, Gago FE, et al. Corticotropinreleasing hormone, luteinizing hormone-releasing hormone, growth hormonereleasing hormone, and somatostatin-like immunoreactivities in biopsies from breast cancer patients. Breast Cancer Res Treat 1990;15:175-84.

[10] Conn PM, Staley D, Harris C, Andrews WV, Gorospe WC, McArdle CA, et al. Mechanism of action of gonadotropin releasing hormone. Annu Rev Physiol 1986;48:495-513.

[11] Fekete M, Wittliff JL, Schally AV. Characteristics and distribution of receptors for [D-TRP6]-luteinizing hormone-releasing hormone, somatostatin, epidermal growth factor, and sex steroids in 500 biopsy samples of human breast cancer. J Clin Lab Anal 1989;3:137-47.

[12] Finch AR, Green L, Hislop JN, Kelly E, McArdle CA. Signaling and antiproliferative effects of type I and II gonadotropin-releasing hormone receptors in breast cancer cells. J Clin Endocrinol Metab 2004;89:1823-32.

[13] Goel S, Sharma R, Hamilton A, Beith J. LHRH agonists for adjuvant therapy of early breast cancer in premenopausal women. Cochrane Database Syst Rev 2009:CD004562.

[14] Kahanpaa KV, Wahlstrom T, Grohn P, Heinonen E, Nieminen U, Widholm O. Sarcomas of the uterus: a clinicopathologic study of 119 patients. Obstet Gynecol 1986;67:417-24.

[15] Kaprara A, Pazaitou-Panayiotou K, Chemonidou MC, Constantinidis TC, Lambropoulou M, Koffa M, et al. Distinct distribution of corticotropin releasing factor receptors in human breast cancer. Neuropeptides 2010;44:355-61.

[16] Kauffman AS. Emerging functions of gonadotropin-releasing hormone II in mammalian physiology and behaviour. J Neuroendocrinol 2004;16: 794-806.

[17] Kim JW, Song JY, Lee JM, Lee JK, Lee NW, Yeom BW, et al. Expression of pituitary tumor-transforming gene in endometrial cancer as a prognostic marker. Int J Gynecol Cancer 2008.

[18] Konski A, Domenico D, Tyrkus M, Irving D, Neisler J, Phibbs G, et al. Prognostic characteristics of surgical stage I endometrial adenocarcinoma. Int J Radiat Oncol Biol Phys 1996;35:935-40.

[19] Kottler ML, Starzec A, Carre MC, Lagarde JP, Martin A, Counis R. The genes for gonadotropin-releasing hormone and its receptor are expressed in human breast with fibrocystic disease and cancer. Int J Cancer 1997;71:595-9.

[20] Limonta P, Moretti RM, Marelli MM, Dondi D, Parenti M, Motta M. The luteinizing hormone-releasing hormone receptor in human prostate cancer cells: messenger ribonucleic acid expression, molecular size, and signal transduction pathway. Endocrinology 1999;140:5250-6.

[21] Livak KJ, Schmittgen TD. Analysis of relative gene expression data using real-time quantitative PCR and the 2(-Delta Delta C(T)) Method. Methods 2001;25:402-8.

[22] Mangia A, Tommasi S, Reshkin SJ, Simone G, Stea B, Schittulli F, et al. Gonadotropin releasing hormone receptor expression in primary breast cancer: comparison of immunohistochemical, radioligand and Western blot analyses. Oncol Rep 2002;9:1127-32.

[23] Millar RP. GnRHs and GnRH receptors. Anim Reprod Sci 2005;88:5-28.

[24] Miller WR, Scott WN, Morris R, Fraser HM, Sharpe RM. Growth of human breast cancer cells inhibited by a luteinizing hormone-releasing hormone agonist. Nature 1985;313:231-3.

[25] Morimoto C, Osuga Y, Yano T, Takemura Y, Harada M, Hirata T, et al. GnRH II as a possible cytostatic regulator in the development of endometriosis. Hum Reprod 2005;20:3212-8.

[26] Nagy A, Schally AV. Targeting of cytotoxic luteinizing hormone-releasing hormone analogs to breast, ovarian, endometrial, and prostate cancers. Biol Reprod 2005;73:851-9.

[27] Newcomb PA, Solomon C, White E. Tamoxifen and risk of large bowel cancer in women with breast cancer. Breast Cancer Res Treat 1999;53: 271-7.

[28] Pawson AJ, Morgan K, Maudsley SR, Millar RP. Type II gonadotrophin-releasing hormone (GnRH-II) in reproductive biology. Reproduction 2003;126:271-8.

[29] Peng C, Fan NC, Ligier M, Vaananen J, Leung PC. Expression and regulation of gonadotropin-releasing hormone $(\mathrm{GnRH})$ and $\mathrm{GnRH}$ receptor messenger ribonucleic acids in human granulosa-luteal cells. Endocrinology 1994;135:1740-6.

[30] Pfisterer J, Kommoss F, Sauerbrei W, Rendl I, Kiechle M, Kleine W, et al. Prognostic value of DNA ploidy and S-phase fraction in stage I endometrial carcinoma. Gynecol Oncol 1995;58:149-56.

[31] Sedgley KR, Finch AR, Caunt CJ, McArdle CA. Intracellular gonadotropinreleasing hormone receptors in breast cancer and gonadotrope lineage cells. J Endocrinol 2006;191:625-36. 
[32] Simopoulos C, Christodoulou E, Lambropoulou M, Tsaroucha AK, Kakolyris S, Polychronidis A, et al. Neuropeptide urocortin 1 and its receptors are expressed in the human liver. Neuroendocrinology 2009;89:315-26.

[33] Straub B, Muller M, Krause H, Schrader M, Miller K. Real-time quantitative reverse transcriptase-polymerase chain reaction for luteinizing hormonereleasing hormone receptor gene mRNA expression in human prostate cancer. Urology 2003;62:172-6.
[34] Tieva A, Wilkstrom P, Olofsson JI, Bergh A, Damber JE. Expression of gonadotropin-releasing hormone receptor mRNA in the rat ventral prostate and dunning R3327 PAP adenocarcinoma before and after castration. Prostate 1999;39:101-7.

[35] von Alten J, Fister S, Schulz H, Viereck V, Frosch KH, Emons G, et al. GnRH analogs reduce invasiveness of human breast cancer cells. Breast Cancer Res Treat 2006;100:13-21. 